\title{
Meninjau Hubungan Antara Penggunaan Media Sosial dan Orientasi Pasar Terhadap Kinerja Bisnis Sektor UMKM Acai Sudirman ${ }^{1^{*}}$, Fitria Halim ${ }^{2}$, Anju Bhernadetha Nainggolan ${ }^{3}$, Novita Butarbutar ${ }^{4}$, Sherly ${ }^{5}$ \\ Sekolah Tinggi Ilmu Ekomomi Sultan Agung ${ }^{1,2,4,5}$ Universitas Efarina ${ }^{3}$ \\ E-mail address: acaivenly@stiesultanagung.ac.id* fitriahalim2839@stiesultanagung.ac.id, nainggolan.anju@gmail.com, novita@stiesultanagung.ac.id, sherly@stiesultanagung.ac.id
}

\begin{abstract}
Abstrak: Pada era digitalisasi saat ini, strategi pemasaran pada sektor UMKM dituntut untuk beradaptasi dengan cepat sesuai dengan perkembangan teknologi dan kebutuhan konsumen yang semakin kompleks. Marketing digital menjadi suatu hal yang wajib dari tahun ke tahun baik oleh perusahaan mikro, kecil maupun perusahaan besar. Salah satu cara untuk beradaptasi dan mengembangkan bisnis yang saat ini sedang popular adalah dengan penggunaan content marketing berbasis media sosial dan orientasi pasar. Tujuan utama penelitian mengetahui pengaruh peran media sosial dan orientasi pasar terhadap kinerja bisnis sektor UMKM yang ada di Kota Pematangsiantar. Penelitian ini menggunakan desain penelitian kepustakaan dan lapangan dengan pendekatan kuantitatif kausalitas. Pengumpulan data di lapangan menggunakan dengan kuesioner yang diukur dengan beberapa pertanyaan terkait media sosial, orientasi pasar dan kinerja bisnis. Untuk analisis data menggunakan metode PLS-SEM dan teknik pengumpulan data memakai proportionate stratified random sampling, sehingga sampel dalam penelitian ini berjumlah 240 responden. Hasil penelitian menunjukkan media sosial dan orientasi pasar memiliki pengaruh yang signifikan terhadap kinerja bisnis UMKM di Kota Pematangsiantar.
\end{abstract}

Kata Kunci: Media Sosial, Orientasi Pasar, Kinerja Bisnis, UMKM

Strategi bisnis digital telah meningkat baru-baru ini dikarenakan adanya peningkatan yang mengesankan pada sistem informasi, komunikasi, dan konektivitas teknologi (Garcia-Morales et al., 2017). Kemunculan teknologi media sosial telah menyediakan platform bagi pelaku usaha maupun bisnis untuk berinteraksi dan berkomunikasi dengan pelanggan, pemasok, pengecer, dan pemangku kepentingan lainnya. Teknologi ini melayani beberapa tujuan, termasuk yang berkaitan dengan komunikasi dan kegiatan pemasaran (Abbas et al., 2019). Dalam dunia bisnis, penggunaan media sosial mulai populer dipergunakan sebagai media untuk melakukan komunikasi pemasaran secara online. Hal ini terkait dengan manfaat yang dirasakan lebih praktis dan efisien bagi perusahaan maupun pelanggan (Omotosho, 2020). Komunikasi dan kolaborasi pemasaran dengan media sosial saat ini bertujuan meningkatkan pertukaran informasi yang efektif dan tepat waktu di seluruh rantai pasokan usaha (Cao et al., 2018). Pemasaran dengan media sosial sangat penting bagi usaha mikro, kecil dan menengah untuk mengembangkan kemampuan pemasarannya. Umumnya, usaha mikro, kecil dan menengah memiliki sumber daya keuangan dan manajerial yang 
terbatas untuk mendukung kegiatan pemasaran (Tarsakoo \& Charoensukmongkol, 2020).

Penelitian yang dilakukan oleh Chai et al., (2011), menyimpulkan media sosial memiliki peranan besar dalam peningkatan kinerja bisnis usaha. Penerapan pemasaran menggunakan media sosial merupakan hal yang krusial untuk dilakukan sebagai upaya untuk memahami kebutuhan, keinginan, dan permintaan pasar. Hasil studi yang dilakukan (Kaplan \& Haenlein, 2010), membuktikan perkembangan bisnis tidak terlepas dari keterlibatan penggunaan media sosial yang implikasinya meningkatkan efisiensi yang tinggi daripada menggunakan komunikasi pemasaran tradisional. Meskipun pemasaran media sosial memberikan peluang dan manfaat baru bagi beberapa perusahaan, penelitian Weber (2009), menunjukkan bahwa banyak inisiatif pemasaran media sosial yang dilaksanakan oleh usaha kecil dan usaha menengah (UKM) cenderung tidak berhasil. Hal ini diperkuat dengan hasil penelitian Nakara et al., (2012), yang mengkaji permasalahan UKM dalam mengadopsi pemasaran dengan penggunaan media sosial, seperti masalah dalam menangani teknologi, kurangnya pemahaman tentang peluang yang disediakan oleh media sosial dan bagaimana media sosial dapat digunakan.

Secara praktis, meningkatkan kinerja bisnis sektor UMKM tidak hanya dipengaruhi oleh orientasi kewirausahaan dan penggunaan media sosial tetapi juga dapat dipengaruhi berdasarkan orientasi pasar yang diterapkan pada sistem pemasaran (Solikahan \& Mohammad, 2019) dan (Yasa et al., 2020). Menurut Maydeu-Olivares \& Lado (2003), orientasi pasar dapat diartikan sebagai metode perusahaan untuk menciptakan kinerja yang unggul dan perilaku yang diperlukan untuk meningkatkan kinerja perusahaan. Kinerja bisnis yang optimal dapat dicapai dengan menerapkan budaya yang berorientasi pasar, keinginan dan tuntutan dari pasar tersebut (Andriyanto \& Sufian, 2017). Pelaku usaha dapat menilai kinerja internal atau eksternal mereka dengan menentukan pencapaian pasar produk mereka. Secara eksternal, kinerja perusahaan dapat ditingkatkan dengan pendekatan yang berorientasi pasar (Giantari \& Jatra, 2019). Maka dari itu, orientasi pasar memiliki peran penting dalam meningkatkan kinerja bisnis suatu usaha. Namun penelitian Solikahan \& Mohammad (2019), menghasilkan penelitian yang berbeda terkait orientasi pasar yang tidak memiliki pengaruh yang signifikan terhadap perkembangan kinerja bisnis perusahaan. Orientasi pasar yang tidak memperhatikan keinginan dan kebutuhan konsumen ternyata tidak mampu mendorong peningkatan kinerja bisnis usaha.

Perkembangan usaha mikro, kecil menengah telah memberikan dampak yang positif pada penyerapan tenaga kerja secara nasional (Maya, 2016). Usaha mikro, kecil dan menengah merupakan rumpun ekonomi produktif yang dimilliki oleh perorangan atau badan usaha sesuai dengan kriteria yang ditetapkan dalam Undang-undang No. 20 Tahun 2008. Dalam perekonomian Indonesia, UMKM memegang peranan penting karena terbukti tahan terhadap berbagai goncangan krisis 
ekonomi dan telah diatur dalam payung hukum berdasarkan undangundang yang telah ditetapkan pemerintah. Saat ini pemerintah berkomitmen dan mengupayakan percepatan akses dan transfer teknologi sebagai stimulus untuk mendorong pelaku UKM yang inovatif agar mampu bersaing dengan para pelaku UKM asing (Slamet et al., 2016). Masyarakat yang berperan sebagai followers dapat melakukan pengadopsian digital marketing dengan penggunaan media sosial sebagai harapan dapat menyentuh berbagai lini masyarakat. Urgensi kegunaan media sosial oleh pelaku UMKM adalah sebagai media komunikasi yang efektif dalam membantu keputusan bisnis (Priambada, 2015).

Saat ini, perhatian terhadap kinerja UMKM sangatlah tinggi dikarenakan dapat membantu menghilangkan blokade dan menghasilkan prospek yang luas bagi UMKM untuk berkembang juga untuk bersaing kuat di pasar regional maupun global (Aminu \& Shariff, 2015). Oleh karena itu, pelaku usaha sangat bertanggung jawab untuk mengelola UMKM dan mencoba untuk mendapatkan UKM yang lebih baik dari kinerja yang dihasilkan melalui prosedur, rencana, dan strategi baru selama siklus hidup kewirausahaan (Rugraff \& Hansen, 2011). Tujuan penilaian kinerja bisnis pada sektor UMKM adalah untuk meningkatkan pertumbuhan bisnis, mengejar peluang bisnis dari sisi internal maupun eksternal dan pengembangan seluruh kompetensi yang dimiliki pelaku usaha (Salam et al., 2019). Proses kristalisasi kinerja bisnis jika ditinjau dari perspektif penciptaan nilai bagi pelanggan berorientasi pada proses untuk menyebarluaskan nilai-nilai keunggulan kompetitif perusahaan secara optimal (Garg et al., 2020). Hal ini tentu saja membutuhkan beberapa keterampilan dan sistem umpan balik yang memungkinkan pelaku usaha memahami kebutuhan dan harapan konsumen. Pada titik inilah seorang wirausahawan memerlukan tindakan konkret melalui penggunaan media sosial dan penerapan orientasi pasar agar dapat menghasilkan kinerja bisnis yang diharapkan (Omotosho, 2020) dan (Fernandes et al., 2020).

Teknologi media sosial adalah serangkaian aplikasi yang berbasis internet dan dibangun di atas dasar teknologi Web 2.0 yang memungkinkan pengembangan dan pertukaran konten yang dihasilkan penggunanya (Sfetcu, 2017). Media sosial merupakan salah satu media yang berkembang dalam sepuluh tahun terakhir. Media sosial berkembang sejalan dengan perkembangan informasi teknologi yang terjadi pada setiap lini usaha maupun bisnis (Yasa et al., 2020). Penggandaan penggunaan media sosial untuk meningkakan kinerja UMKM telah digambarkan sebagai masalah persuasif dalam proses tumbuhnya aktivitas kewirausahaan (Bughin et al., 2017). Penggunaan media sosial menekankan pentingnya strategi bisnis digital yang berorientasi pada perubahan cara kita berkomunikasi, berkolaborasi, mengonsumsi, dan berkreasi atas suatu produk (Garcia-Morales et al., 2017). Platform media sosial memberikan peluang baru bagi pelaku bisnis untuk meningkatkan kualitasnya melalui cara-cara baru yang interaktif (Chikandiwa et al., 2013). Temuan Ahmad et al., (2019), menyampaikan pendapat yang 
berbeda berdasarkan hasil penelitian yang mereka temukan, yang menyatakan media sosial tidak berpengaruh signifikan terhadap kinerja bisnis.

Dalam teori orientasi pasar, dapat dikatakan bahwa orientasi pasar sangat penting sebagai sebuah perusahaan dalam menempatkan pasar sebagai kunci kelangsungan hidup perusahaan. Oleh karena itu, pasar harus dikelola secara optimal dengan upaya sistematis dari pengelolaan informasi kebutuhan pelanggan sehingga dapat memberikan kepuasan kepada pelanggan (Giantari \& Jatra, 2019). Orientasi pasar adalah aset yang berharga, langka, tidak dapat ditiru secara sempurna, dan tidak tergantikan yang mampu menghasilkan keunggulan kompetitif yang berkelanjutan bagi usaha (Fernandes et al., 2020). Perusahaan yang menjadikan pelanggan sebagai fokus utama bagi perusahaan untuk menjalankan bisnisnya adalah perusahaan yang berorientasi pada pasar (Syafruddin et al., 2020). Selain itu, orientasi pasar memiliki kontribusi dalam aspek pemasaran usaha yang berhubungan dengan perspektif penjualan ke perspektif konsumen dan dari apa perusahaan tawarkan kepada apa yang diinginkan konsumen (Sampaio et al., 2019). Lebih lanjut penelitian Solikahan \& Mohammad (2019), menyatakan orientasi pasar tidak memiliki pengaruh yang signfikan terhadap kinerja bisnis.

Beberapa kasus penelitian di atas menunjukkan adanya perbedaan hasil penelitian yang menunjukkan research gap pada bidang kajian kinerja bisnis. Kesenjangan hasil penelitian yang disimpulkan dari beberapa penelitian sebelumnya membuka celah bagi penelitian ini untuk mengkaji kembali faktor-faktor yang diduga dapat mempengaruhi kinerja bisnis. Oleh karena itu, penting untuk dilakukan penelitian lebih lanjut terkait hubungan antara strategi penggunaan media sosial dan orientasi pasar dalam meningkatkan kinerja bisnis UMKM agar lebih optimal. Tujuan dari penelitian ini adalah untuk mengetahui pengaruh media sosial dan orientasi pasar terhadap kinerja bisnis sektor UMKM yang ada di Kota Pematangsiantar, Sumatera Utara, Indonesia. Selanjutnya untuk kerangka pemikiran dalam penelitian ini dapat dijelaskan pada gambar 1 berikut ini:

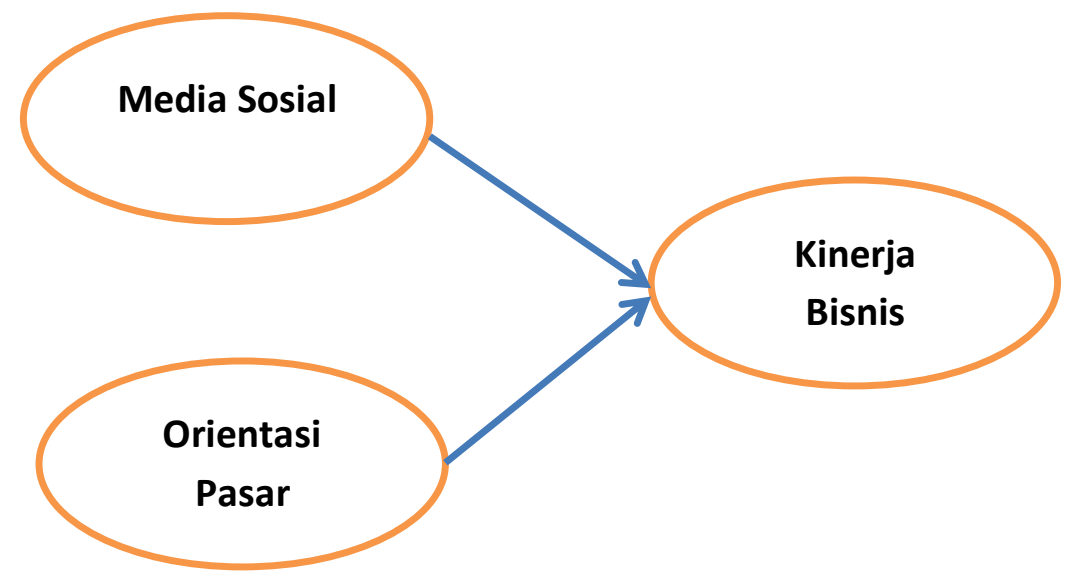

Gambar 1. Kerangka Pemikiran Penelitian 


\section{Metode}

Penelitian ini menggunakan metode dengan pendekatan kuantitatif kausalitas dengan model teoritis yang dinilai dengan analisis PLS-SEM dalam proses dua tahap. Pertama, data penelitian yang dianalisis validitas dan reliabilitasnya dengan menggunakan pengujian cronbachs alpha, composite reliability, outer loading dan average variance exctracted. Kemudian, melakukan analisis Analisis Faktor Konfirmatori untuk memeriksa kecocokan model dan keandalan model serta membahas hipotesis melalui Structural Equation Model (SEM) berbasis varians (Hair, 2014). Penentuan jumlah sampel dilakukan secara proportionate stratified random sampling sebanyak 30 sampel untuk masing-masing Kecamatan yang ada di Kota Pematangsiantar yang terdiri Kecamatan Siantar Timur, Siantar Barat, Siantar Utara, Siantar Selatan, Siantar Marihat, Siantar Martoba, Siantar Sitalasari, Siantar Marimbum. Jumlah sampel dalam penelitian ini sebanyak 240 responden. Instrumen yang dipakai untuk penelitian ini memakai kuisioner dengan menggunakan skala likert, yaitu (1) yang menyatakan "sangat tidak setuju hingga" (5) "sangat setuju". Pengukuran variabel dependen dan independen menggunakan referensi terdahulu yang memiliki relevansi dengan topik penelitian dan variabel penelitian. Pengukuran variabel dependen, yaitu kinerja bisnis diukur dengan menggunakan penelitian terdahulu (Garg et al., 2020); (Kaur et al., 2019) yang terdiri dari 2 item. Kemudian untuk variabel independen pertama, yaitu media sosial diukur dengan menggunakan penelitian terdahulu (Tajudeen et al., 2018); (Teo \& Pian, 2003); (Lee \& Kozar, 2009); (Chai et al., 2011), yang terdiri dari 4 item, independen kedua, yaitu orientasi pasar diukur dengan menggunakan penelitian terdahulu (Sampaio et al., 2019); (Mahmoud, 2011); (Syafruddin et al., 2020), yang terdiri dari 3 item. Adapun penjelasan mengenai item yang digunakan dalam penelitian ini dapat dijelaskan pada tabel 1 berikut ini:

Tabel 1. Pengukuran Variabel Penelitian

\begin{tabular}{|c|c|c|c|}
\hline Variabel & Code & Item & Referensi \\
\hline $\begin{array}{l}\text { Media } \\
\text { Sosial }\end{array}$ & $\begin{array}{l}\text { MS1 } \\
\text { MS2 } \\
\text { MS3 } \\
\text { MS4 }\end{array}$ & $\begin{array}{l}\text { Kompabilitas Media Sosial } \\
\text { Interaktivitas Media Sosial } \\
\text { Penggunaan Media Sosial } \\
\text { Jaminan Struktural Media } \\
\text { Sosial }\end{array}$ & $\begin{array}{l}\text { Tajudeen et al., } \\
\text { (2018); Teo \& Pian, } \\
\text { (2003); (Lee \& } \\
\text { Kozar (2009); Chai } \\
\text { et al., (2011) }\end{array}$ \\
\hline $\begin{array}{l}\text { Orientasi } \\
\text { Pasar }\end{array}$ & $\begin{array}{l}\text { OP1 } \\
\text { OP2 } \\
\text { OP3 }\end{array}$ & $\begin{array}{c}\text { Orientasi Pelanggan } \\
\text { Orientasi Pesaing } \\
\text { Informasi Pasar }\end{array}$ & $\begin{array}{l}\text { Sampaio et al., } \\
\text { (2019); Mahmoud } \\
\text { (2011); Syafruddin } \\
\text { et al., (2020) }\end{array}$ \\
\hline $\begin{array}{l}\text { Kinerja } \\
\text { Bisnis }\end{array}$ & KB1 & Kinerja Keuangan & $\begin{array}{l}\text { Garg et al., (2020); } \\
\text { Kaur et al., (2019) }\end{array}$ \\
\hline
\end{tabular}


\begin{tabular}{|l|l|l|}
\hline & KB2 & Kinerja Pemasaran \\
\hline
\end{tabular}

Sumber: Beberapa Referensi Terdahulu

\section{Hasil dan Pembahasan}

Penyebaran kuesioner dilakukan secara konvensional dengan menyebarkan langsung kepada pelaku UMKM yang ada di Kota Pematangsiantar dengan tetap memperhatikan protokol kesehatan. Berdasarkan hasil pengumpulan data di lapangan diperoleh data yang valid sebanyak 240 responden. Karakteristik responden dalam penelitian ini akan diuraikan dengan tabel 2 yang terdiri dari profil umum responden dan informasi umum usaha.

Tabel 2. Profil Umum Responden

\begin{tabular}{|c|c|c|c|}
\hline Kategori & Detail & $\begin{array}{c}\text { Jumlah } \\
\text { Responden }\end{array}$ & Persentase \\
\hline Jenis Kelamin & $\begin{array}{c}\text { Pria } \\
\text { Wanita }\end{array}$ & $\begin{array}{c}142 \\
98\end{array}$ & $\begin{array}{l}59,17 \% \\
40,83 \%\end{array}$ \\
\hline Usia & $\begin{array}{l}\text { 20-29 tahun } \\
30-39 \text { tahun } \\
40-49 \text { tahun } \\
\text { 50-59 tahun } \\
60-69 \text { tahun }\end{array}$ & $\begin{array}{l}14 \\
71 \\
84 \\
51 \\
20\end{array}$ & $\begin{array}{c}5,83 \% \\
29,58 \% \\
35 \% \\
21,26 \% \\
8,33 \%\end{array}$ \\
\hline $\begin{array}{c}\text { Tingkat } \\
\text { Pendidikan }\end{array}$ & $\begin{array}{c}\text { SMP } \\
\text { SMA } \\
\text { D1 s/d D3 } \\
\text { Sarjana } \\
\text { Magister }\end{array}$ & $\begin{array}{c}12 \\
144 \\
49 \\
33 \\
2 \\
\end{array}$ & $\begin{array}{c}5 \% \\
60 \% \\
20,42 \% \\
13,75 \% \\
0,83 \% \\
\end{array}$ \\
\hline Lama Usaha & $\begin{array}{l}<1 \text { Tahun } \\
\text { 1-3 Tahun } \\
\text { 4-6 Tahun } \\
>6 \text { Tahun }\end{array}$ & $\begin{array}{l}97 \\
78 \\
53 \\
12\end{array}$ & $\begin{array}{c}40,42 \% \\
32,5 \% \\
22,08 \% \\
5 \% \\
\end{array}$ \\
\hline Jenis Usaha & $\begin{array}{c}\text { Kuliner } \\
\text { Teknologi } \\
\text { Fashion } \\
\text { Kosmetik } \\
\text { Otomotif } \\
\text { Event Organizer } \\
\text { Agrobisnis }\end{array}$ & $\begin{array}{c}142 \\
2 \\
20 \\
43 \\
21 \\
7 \\
5\end{array}$ & $\begin{array}{c}59,17 \% \\
0,83 \% \\
8,33 \% \\
17,92 \% \\
8,75 \% \\
2,92 \% \\
2,08 \%\end{array}$ \\
\hline $\begin{array}{l}\text { Media Sosial } \\
\text { Yang Sering } \\
\text { Digunakan }\end{array}$ & $\begin{array}{c}\text { Instagram } \\
\text { Facebook } \\
\text { Twitter } \\
\text { WhatsApp } \\
\text { Path }\end{array}$ & $\begin{array}{c}144 \\
70 \\
8 \\
16 \\
2\end{array}$ & $\begin{array}{c}60 \% \\
29,17 \% \\
3,33 \% \\
6,67 \% \\
0,83 \%\end{array}$ \\
\hline $\begin{array}{c}\text { Intensitas } \\
\text { Penggunaan } \\
\text { Media Sosial }\end{array}$ & $\begin{array}{c}\text { Sekali } \\
2-5 \text { Kali } \\
\text { Lebih Dari } 5 \text { Kali }\end{array}$ & $\begin{array}{l}117 \\
81 \\
40\end{array}$ & $\begin{array}{l}48,75 \% \\
33,75 \% \\
16,67 \%\end{array}$ \\
\hline
\end{tabular}




\begin{tabular}{|c|c|c|c|} 
Dalam & Tidak Pernah & 2 & $0,83 \%$ \\
\hline
\end{tabular}

Sumber: Olahan Data (2020)

\section{Pengukuran Outler Model}

Hasil data yang diperoleh dari kuesioner penelitian diolah menggunakan aplikasi SmartPLS versi 3.2.8 dengan panduan pengelolaan dari (Juliandi, 2018). Dalam pengukuran outer model, pengujian yang dilakukan adalah uji validitas dan uji realibilitas. Pengujian validitas konvergen yang ditentukan oleh loading factor dan AVE dengan syarat loading factor diatas 0,7 dan nilai AVE sebesar 0,5 (Hair, 2014). Pengujian reliabilitas model menurut (Hair, 2014), dilihat dari nilai Cronbanch's alpha dan composite reliability (CR) yang memiliki nilai lebih besar dari 0,7. Dari gambar 2 dan tabel 4 serta tabel 5 di bawah ini, dapat disimpulkan bahwa nilai masing-masing alat ukur yang digunakan dalam penelitian ini adalah valid dan reliabel.

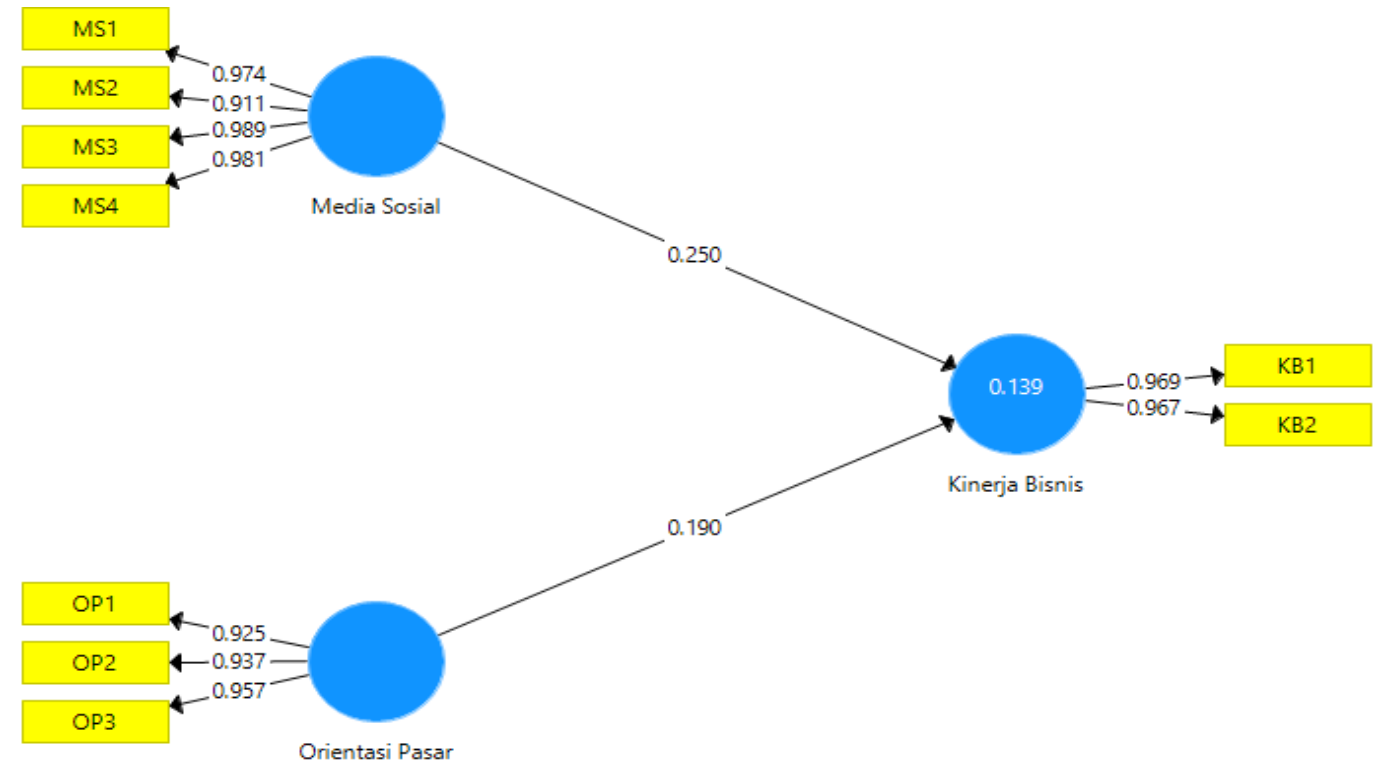

Gambar 2. Tampilan Outler Model

Tabel 3. Hasil Pengukuran Outler Model

\begin{tabular}{|l|c|r|r|}
\hline Keterangan & $\begin{array}{c}\text { Cronbach's } \\
\text { Alpha }\end{array}$ & $\begin{array}{c}\text { Composite } \\
\text { Reliability }\end{array}$ & $\begin{array}{c}\text { Average Variance } \\
\text { Extracted (AVE) }\end{array}$ \\
\hline Media Sosial & 0,974 & 0,981 & 0,929 \\
\hline Orientasi Pasar & 0,934 & 0,958 & 0,883 \\
\hline Kinerja Bisnis & 0,933 & 0,967 & 0,937 \\
\hline
\end{tabular}

Sumber: Olahan Data (2020)

Tabel 4. Hasil Loading Factor

\begin{tabular}{|l|r|c|l|}
\hline Keterangan & $\begin{array}{c}\text { Perceived Ease } \\
\text { of Use }\end{array}$ & $\begin{array}{c}\text { Perceived } \\
\text { Usefulness }\end{array}$ & Behavioral Intention \\
\hline MS1 & 0,974 & & \\
\hline MS2 & 0,911 & & \\
\hline
\end{tabular}




\begin{tabular}{|l|r|r|r|} 
MS3 & 0,989 & & \\
\hline MS4 & 0,981 & & \\
\hline OP1 & & 0,925 & \\
\hline OP2 & & 0,937 & \\
\hline OP3 & 0,957 & 0,969 \\
\hline KB1 & & 0,967 \\
\hline KB2 & & & \\
\hline
\end{tabular}

Sumber: Olahan Data (2020)

Pada pengujian uji validitas yang disajikan pada tabel 3 dan 4 di atas, nilai masing-masing loading factor dan AVE pada indikator variabel perceived ease of use, perceived usefulness, trust, social influence dan behavioral intention berada pada di atas 0,7 untuk loading factor dan di atas 0,5 untuk AVE. Selanjutnya nilai untuk masing-masing reliabilitas di atas diperoleh nilai composite reliability untuk masing-masing variabel penelitian adalah di atas 0,7 yang dapat dijelaskan sebagai berikut: media sosial memperoleh 0,981 , orientasi pasar memperoleh 0,958 , dan kinerja bisnis memperoleh 0,967. Selanjutnya untuk nilai cronbach's alpha diperoleh nilai untuk masing-masing variabel di atas 0,60 hal ini menunjukkan bahwa semua variabel penelitian mempunyai nilai reliabilitas yang baik.

\section{Pengukuran Inner Model}

Pengukuran inner model dilakukan dengan cara bootstrapping data hasil penelitian menggunakan SmartPLS 3.2.8. Ada dua hasil yang diperoleh dari bootstrapping, yang pertama adalah signifikansi dari dua variabel terkait, dan juga R-square penelitian. Nilai dari R-square adalah nilai yang menunjukan kemampuan variabel- variabel eksogen membangun variabel endogen. Menurut Chin et al., (2008), ada tiga kategori dari nilai R-square, jika nilai $\mathrm{R}$-square adalah 0,19 hubungan antara variabel eksogen membentuk variabel endogen adalah lemah, jika bernilai 0,33 artinya hubungannya moderat dan jika nilainya adalah 0,67 pertanda bahwa hubungannya kuat. Sedangkan, (Sarwono, 2016) menyatakan bahwa jika nilai R- square nya lebih dari 0,67 maka hubungan antar endogen dan eksogennya adalah sangat kuat.

Tabel 5. Hasil Perhitungan nilai R-Square

\begin{tabular}{|c|c|c|}
\hline Keterangan & R Square & R Square Adjusted \\
\hline Kinerja Bisnis & 0.139 & 0.132 \\
\hline
\end{tabular}

Sumber: Olahan Data (2020)

Dilihat dari nilai R-square variabel endogennya, nilainya berkisar antara 0,10-0,19 ini menunjukan bahwa secara keseluruhan kemampuan variabel variabel eksogen menjelaskan endogen adalah lemah. Selanjutnya untuk membuktikan pengujian hipotesis, maka dilakukan uji signifikansi yang digunakan untuk mengetahui hubungan antara variabel eksogen terhadap variabel endogennya. Kriteria signifikannya adalah dilihat dari nilai $p$-value. Dengan tingkat signifikansi $5 \%$, jika nilai $p$-value 
antara variabel eksogen dan endogen besarnya kurang dari 0,05 artinya variabel eksogen berpengaruh secara signifikan terhadap variabel endogen, sebaliknya jika nilainya lebih besar dari 0,05 artinya variabel eksogen tidak berpengaruh secara signifikan dalam membangun variabel endogennya.

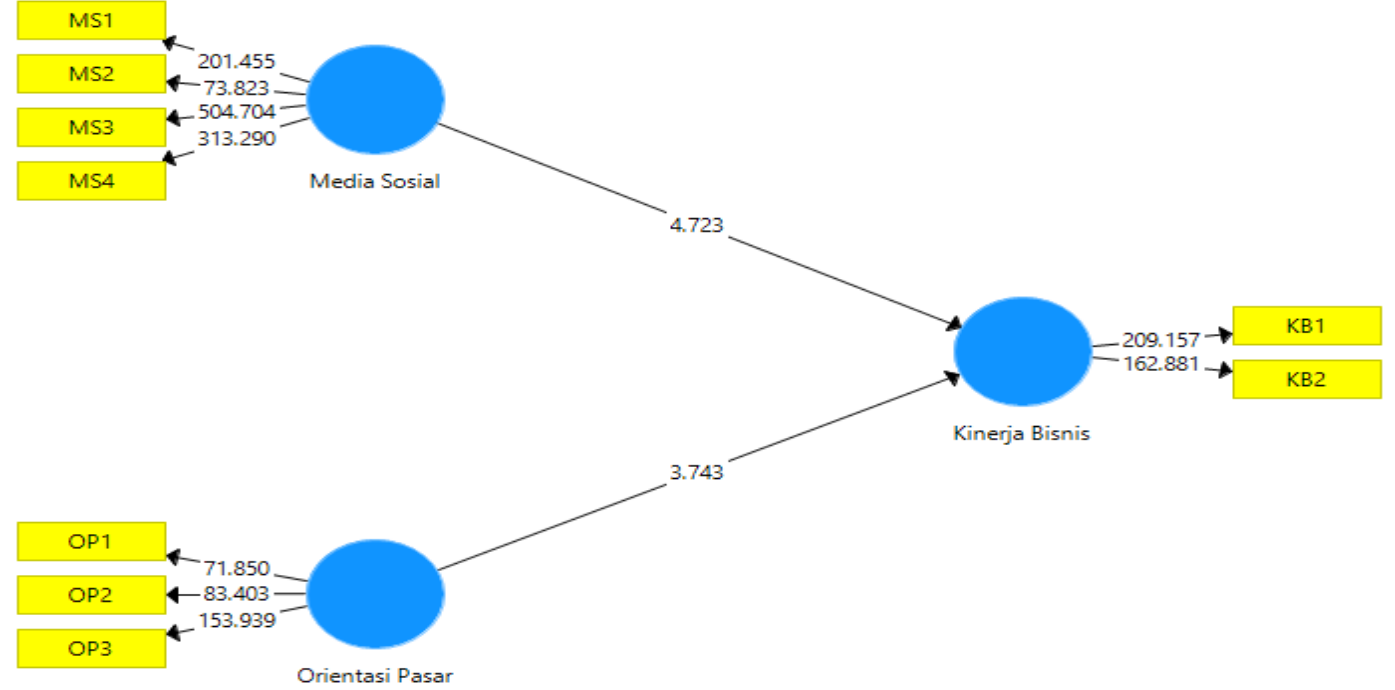

Gambar 3. Tampilan Inner Model

Tabel 6. Hasil Uji Path Coefficients

\begin{tabular}{|l|c|c|c|c|}
\hline \multicolumn{1}{|c|}{ Path Antar Variabel } & Koefisien & thitung & $\boldsymbol{P}$-Value & Kesimpulan \\
\hline $\begin{array}{l}\text { Media sosial >> Kinerja } \\
\text { bisnis }\end{array}$ & 0.250 & 4.273 & $\mathbf{0 . 0 0 0}$ & Signifikan \\
\hline $\begin{array}{l}\text { Orientasi pasar >> Kinerja } \\
\text { bisnis }\end{array}$ & 0.190 & 3.743 & $\mathbf{0 . 0 0 0}$ & Signifikan \\
\hline
\end{tabular}

Sumber: Olahan Data (2020)

Berdasarkan hasil olahan data yang disajikan pada tabel 6 di atas, uji signifikansi hubungan langsung antara variabel eksogen dan endogen dapat dikatakan secara keseluruhan variabel eksogen berpengaruh secara signifikan terhadap variabel endogennya. Dari 2 hipotesis yang dikembangkan semua dinyatakan diterima, yaitu untuk pengaruh antara variabel media sosial terhadap variabel kinerja bisnis berpengaruh secara signifikan. Selanjutnya untuk pengaruh antara variabel orientasi pasar terhadap variabel kinerja bisnis juga memiliki pengaruh yang signifikan.

\section{Pembahasan}

\section{Pengaruh Media Sosial Terhadap Kinerja Bisnis}

Hasil penelitian menunjukkan bahwa media sosial berpengaruh positif dan signifikan terhadap kinerja bisnis. Hasil penelitian ini sesuai dengan temuan studi yang dilakukan Ramdani et al., (2013), yang 
menunjukkan bahwa adopsi teknologi media sosial pada sektor UKM diwajibkan oleh manajemen puncak dengan meminta para karyawan untuk menggunakannya dalam operasi taktis maupun operasi komunikasi pemasaran. Penelitian Yasa et al., (2020), juga menyampaikan hasil yang sama dengan penelitian ini dengan temuan semakin tinggi strategi promosi menggunakan media sosial, maka akan meningkatkan kinerja bisnis dari UKM. Kegiatan promosi dengan menggunakan media sosial dapat meningkatkan omset penjualan, pangsa pasar dan keuntungan bisnis (Zhang \& Ahmed, 2018). Temuan Ahmad et al., (2019), menyampaikan pendapat yang berbeda berdasarkan hasil penelitian yang mereka temukan, yang menyatakan media sosial tidak berpengaruh signifikan terhadap kinerja bisnis. Hal ini disebabkan media sosial kompatibel dengan sebagian besar infrastruktur organisasi usaha yang ada. Temuan Nair (2011), berpendapat penggunaan media sosial adalah proses eksperimental dan hasilnya tidak dapat langsung diukur. Maka dari itu, perlu ada upaya organisasi bisnis menginvestasikan sejumlah modal dalam melaporkan dan mengukur manfaat dari media sosial bagi kinerja bisnis.

\section{Pengaruh Orientasi Pasar Terhadap Kinerja Bisnis}

Hasil penelitian menunjukkan bahwa orientasi pasar berpengaruh positif dan signifikan terhadap kinerja bisnis. Hasil ini sesuai dengan penelitian Udriyah et al., (2019) dan Micheels \& Gow (2015), yang menyatakan perusahaan yang berorientasi pada pasar akan secara terus menerus memindai dan menilai disposisi preferensi pelanggan sehingga menciptakan kinerja bisnis yang lebih baik. Mengadopsi strategi pemasaran yang berorientasi pasar dianggap sebagai salah satu cara yang ampuh untuk mengelola dan meminimalisir dampak perubahan lingkungan eksternal seperti perkembangan teknologi informasi secara global (Mahmoud, 2011). Kemampuan orientasi pasar dapat diubah menjadi dalam bentuk nilai pelanggan dengan memanfaatkan sumber daya yang implikasinya dapat mempengaruhi kinerja UMKM (Mamun et al., 2018). Disisi lain, hasil penelitian ini bertolak belakang dengan penelitian Alhakimi \& Mahmoud (2020) dan Solikahan \& Mohammad (2019), yang menyatakan orientasi pasar tidak memiliki pengaruh yang signfikan terhadap kinerja bisnis. Hal ini bisa terjadi karena mereka tidak bisa menciptakan peluang pasar dan nilai pelanggan (seperti pengalaman, produk atribut, dan persepsi tentang kualitas produk) dalam memenuhi kebutuhan pasar.

\section{Kesimpulan}

Dari hasil pengujian hipotesis yang dilakukan, maka kesimpulan dalam penelitian ini adalah sebagai berikut:

1. Hasil pengujian variabel media sosial menunjukkan bahwa faktor penggunaan media sosial berpengaruh positif dan signifikan terhadap kinerja bisnis. 
2. Hasil pengujian variabel orientasi pasar menunjukkan bahwa faktor orientasi pasar berpengaruh positif dan signifikan terhadap kinerja bisnis.

3. Dilihat dari nilai R-square variabel endogennya, dapat diartikan terdapat hubungan yang lemah antara variabel media sosial, orientasi pasar dan kinerja bisnis.

\section{Keterbatasan dan Saran}

Penelitian ini memiliki keterbatasan dan saran yang kemungkinan dapat mempengaruhi hasil penelitian, yaitu:

1. Penelitian ini hanya terbatas pada pelaku UMKM yang ada di Kota Pematangsiantar yang berjumlah 240 responden, sehingga dirasa masih terlalu kecil dibandingkan dengan jumlah UMKM yang ada di Indonesia. Maka dari itu, untuk penelitian selanjutnya disarankan untuk menambah jumlah sampel dan memilih lokasi atau tempat penelitian lain supaya jangkauan penelitian dapat lebih luas.

2. Dalam penelitian ini, peneliti hanya meneliti 2 variabel independen yaitu media sosial dan orientasi pasar sehingga tidak dapat mencakup dan mengetahui seluruh variabel yang memengaruhi kinerja bisnis sektor UMKM.

3. Untuk penelitian selanjutnya mengenai pengukuran kinerja bisnis UMKM, diharapkan dapat mengembangkan dan mendalami hal-hal yang berkaitan dengan variabel-variabel penelitian sebelumnya, atau dapat juga menambahkan variabel lain yang berkaitan dan belum digunakan dalam penelitian ini misalnya orientasi kewirausahaan, inovasi produk, manajemen kewirausahaan, pengadopsian standar laporan keuangan, dan lain-lain.

\section{Daftar Pustaka}

Abbas, J., Mahmood, S., Ali, H., Raza, M. A., Ali, G., Aman, J., Bano, S., \& Nurunnabi, M. (2019). The Effects Of Corporate Social Responsibility Practices And Environmental Factors Through A Moderating Role Of Social Media Marketing On Sustainable Performance Of Business Firms. Sustainability (Switzerland), 11(12).

Ahmad, S. Z., Abu Bakar, A. R., \& Ahmad, N. (2019). Social media adoption and its impact on firm performance: the case of the UAE. International Journal of Entrepreneurial Behaviour and Research, 25(1), 84-111. https://doi.org/10.1108/IJEBR-08-2017-0299

Alhakimi, W., \& Mahmoud, M. (2020). The Impact Of Market Orientation On Innovativeness: Evidence From Yemeni Smes. Asia Pacific Journal of Innovation and Entrepreneurship, 14(1), 47-59.

Aminu, I. M., \& Shariff, M. N. M. (2015). Influence Of Strategic Orientation On Smes Access To Finance In Nigeria. Asian Social Science, 11(4), 298-309. https://doi.org/10.5539/ass.v11n4p298 
Andriyanto, F., \& Sufian, M. S. (2017). Analisis Pengaruh Orientasi Pasar Dan Inovasi Terhadap Keunggulan Bersaing Dalam Rangka Meningkatkan Kinerja Bisnis. Fakultas Ekonomika dan Bisnis, Universitas Diponegoro.1-20.

Bughin, J., Chui, M., \& Miller, A. (2017). How Companies Are Benefiting from Web 2.0: Mckinsey Global Survey Results, Quarterly, 17 (6), 1 9.

Cao, Y., Ajjan, H., Hong, P., \& Le, T. (2018). Using Social Media For Competitive Business Outcomes: An Empirical Study Of Companies In China. Journal of Advances in Management Research, 15(2), 211235. https://doi.org/10.1108/JAMR-05-2017-0060

Chai, S., Das, S., \& Rao, H. R. (2011). Factors Affecting Bloggers' Knowledge Sharing: An Investigation Across Gender. Journal of Management Information Systems, 28(3), 309-342.

Chikandiwa, S. T., Contogiannis, E., \& Jembere, E. (2013). The Adoption Of Social Media Marketing In South African Banks. European Business Review, 25(4), 365-381. https://doi.org/10.1108/EBR-022013-0013

Chin, W. W., Peterson, R. A., \& Brown, S. P. (2008). Structural equation modeling in marketing: Some practical reminders. Journal of Marketing Theory and Practice, 16(4), 287-298.

Fernandes, C. I. M. A. S., Ferreira, J. J. M., Lobo, C. A., \& Raposo, M. (2020). The Impact Of Market Orientation On The Internationalisation Of SMEs. Review of International Business and Strategy, 30(1), 123143. https://doi.org/10.1108/RIBS-09-2019-0120

Garcia-Morales, V. J., Martín-Rojas, R., \& Lardón-López, M. E. (2017). Influence Of Social Media Technologies On Organizational Performance Through Knowledge And Innovation. Baltic Journal of Management, 13(3), 345-367. https://doi.org/10.1108/BJM-04-20170123

Garg, P., Gupta, B., Dzever, S., Sivarajah, U., \& Kumar, V. (2020). Examining the Relationship between Social Media Analytics Practices and Business Performance in the Indian Retail and IT Industries: The Mediation Role of Customer Engagement. International Journal of Information Management, 52(April 2019), 102069.

Giantari, G. A. K., \& Jatra, M. (2019). The Role of Differentiation Strategy and Innovation in Mediating Market Orientation and the Business Performance. Journal of Business Management and Economic Research, 3(6), 39-60. https://doi.org/10.29226/TR1001.2019.1

Hair, J. F. (2014). Multivariat Data Analysis 7th Edition. Pearson Prentice Hall.

Juliandi, A. (2018). Membangun Model PLS di SmartPLS. 16-17. https://doi.org/10.5281/zenodo.2538001

Kaplan, A. M., \& Haenlein, M. (2010). Users of the World, Unite! The Challenges and Opportunities of Social Media. Business Horizons, 53(1), 59-68. https://doi.org/10.1016/j.bushor.2009.09.003 
Kaur, S., Gupta, S., Singh, S. K., \& Perano, M. (2019). Organizational Ambidexterity Through Global Strategic Partnerships: A Cognitive Computing Perspective. Technological Forecasting and Social Change, 145, 43-54. https://doi.org/10.1016/j.techfore.2019.04.027

Lee, Y., \& Kozar, K. A. (2009). Designing Usable Online Stores: A Landscape Preference Perspective. Information and Management, 46(1), 31-41. https://doi.org/10.1016/j.im.2008.11.002

Mahmoud, M. A. (2011). Market Orientation and Business Performance among SMEs in Ghana. International Business Research, 4(1), 241251. https://doi.org/10.5539/ibr.v4n1p241

Mamun, A., Mohiuddin, M., Fazal, S. A., \& Ahmad, G. Bin. (2018). Effect Of Entrepreneurial And Market Orientation On Consumer Engagement And Performance Of Manufacturing SMEs. Management Research Review, 4(1), 133-147.

Maya, S. (2016). Strategi Peningkatan Penjualan Usaha Kecil Menegah Melalui E- Commerce Studi Kasus : Mitra UKM Perusahaan X. JABE; Journal of Applied Business and Economics, 2(3), 271-279.

Maydeu-Olivares, A., \& Lado, N. (2003). Market orientation and business economic performance: A mediated model. International Journal of Service Industry Management, 14(3-4), 284-309. https://doi.org/10.1108/09564230310478837

Micheels, E. T., \& Gow, H. R. (2015). The Effect of Market Orientation on Learning, Innovativeness, and Performance in Primary Agriculture. Canadian Journal of Agricultural Economics/Revue Canadienne d'agroeconomie, 63(2), 209-233. https://doi.org/10.1111/cjag.12047

Nair, M. (2011). Understanding and Measuring the Value of Social Media. The Journal of Corporate Accounting \& Finance, 45-51.

Nakara, W. A., Benmoussa, F. Z., \& Jaouen, A. (2012). Entrepreneurship And Social Media Marketing: Evidence From French Small Business. International Journal of Entrepreneurship and Small Business, 16(4), 386-405.

Omotosho, B. J. (2020). Small Scale Craft Workers And The Use Of Social Media Platforms For Business Performance In Southwest Nigeria. Journal of Small Business and Entrepreneurship, 1(1), 1-16.

Priambada, S. (2015). Manfaat Penggunaan Media Sosial Pada Usaha Kecil Menengah (UKM). Seminar Nasional Sistem Informasi Indonesia, November, 41-46.

Ramdani, B., Chevers, D., \& Williams, D. A. (2013). SMEs' Adoption Of Enterprise Applications: A Technology-Organisation-Environment Model. Journal of Small Business and Enterprise Development, 20(4), 735-753. https://doi.org/10.1108/JSBED-12-2011-0035.

Rugraff, E., \& Hansen, M.W. (2011). Multinational Corporations and Local Firms in Emerging Economies. University of Chicago Press Economics Books, University of Saparito.

Salam, S., Shams, A., \& Hoque, M. M. (2019). The Role of Social Media and Effect of Relationship Marketing on SME Performance in 
Bangladesh: Multi-Group CFA. Asian People Journal (APJ), 2(1), 1231. www.uniszajournals.com/apj

Sampaio, C. A. F., Hernández-Mogollón, J. M., \& Rodrigues, R. G. (2019). Assessing The Relationship Between Market Orientation And Business Performance In The Hotel Industry - The Mediating Role Of Service Quality. Journal of Knowledge Management, 23(4), 644-663.

Sarwono J. (2016). Membuat Skripsi, Tesis dan Disertasi dengan Partial Least Square SEM (PLS - SEM). Yogyakarta. Penerbit Andi.

Sfetcu, N. (2017). Web 2.0/Social Media/Social Networks; CreateSpace Independent Publishing Platform: Scotts Valley, CA, USA.

Slamet, R., Nainggolan, B., Roessobiyatno, R., Ramdani, H., Hendriyanto, A., \& IIma, L. L. (2016). Strategi Pengembangan UKM Digital Dalam Menghadapi Era Pasar Bebas. Jurnal Manajemen Indonesia, 16(2), 136-147. https://doi.org/10.25124/jmi.v16i2.319

Solikahan, E. Z., \& Mohammad, A. (2019). Entrepreneurial Orientation, Market Solikahan, E. Z., \& Mohammad, A. (2019). Entrepreneurial Orientation, Market Orientation and Financial Orientation in Supporting the Performance of Karawo SMEs in Gorontalo City. Journal of Applied Management (JAM), 17(. Journal of Applied Management (JAM), 17(4), 729-740.

Syafruddin, Asdar, M., Parawansa, D. A., \& Nohong, M. (2020). Pengaruh Orientasi Pasar dan Orientasi Teknologi Terhadap Kinerja Usaha UKM. Equilibrium Journal, 2(1), 1-9.

Tajudeen, F. P., Jaafar, N. I., \& Ainin, S. (2018). Understanding The Impact Of Social Media Usage Among Organizations. Information and Management, 55(3), 308-321.

Tarsakoo, P., \& Charoensukmongkol, P. (2020). Dimensions Of Social Media Marketing Capabilities And Their Contribution To Business Performance Of Firms In Thailand. Journal of Asia Business Studies, 14(4), 441-461. https://doi.org/10.1108/JABS-07-2018-0204

Teo, T. S. H., \& Pian, Y. (2003). A Contingency Perspective On Internet Adoption And Competitive Advantage. European Journal of Information Systems, 12(2), 78-92.

Udriyah, Tham, J., \& Ferdous Azam, S. M. (2019). The Effects Of Market Orientation And Innovation On Competitive Advantage And Business Performance Of Textile Smes. Management Science Letters, 9(9), 1419-1428. https://doi.org/10.5267/j.msl.2019.5.009

Undang-Undang No. 20 Tahun (2008). Tentang Usaha Mikro, Kecil dan Menengah.

Weber, L. (2009). Marketing to the Social Web: How Digital Customer Communities Build Your Business, Wiley, NJ.

Yasa, N. N. K., Giantari, I. G. A. K., Setini, M., Sarmawa, W., Laksmit, P., Rahmayanti, D., \& Dharmanegara, I. B. A. (2020). Service Strategy Based On Tri Kaya Parisudha, Social Media Promotion, Business Values And Business Performance. Management Science Letters, 10(13), 2961-2972. https://doi.org/10.5267/j.msl.2020.5.029 
Zhang, Z., \& Ahmed, W. (2018). A Comparison Of Information Sharing Behaviours Across 379 Health Conditions On Twitter. International Journal of Public Health, 5(Ahmed). 